\title{
実規模覆道におけるケーブルセンサと移動通信網を用いた 落石検知システムに関する研究
}

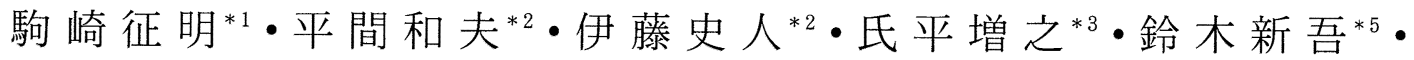 \\ 川村洋平 ${ }^{* 4}$ ・樋口澄志 ${ }^{* 4}$
}

\begin{abstract}
要 旨
岩盤斜面での破壊音や落石の衝突振動を広い範囲にわたって監視できる，すなわち測定範囲を点から線，面へ拡張できる可能性を持つ センサに振動検出用ケーブルセンサがある.この研究では, 実規模覆道内にケーブルセンサを格子状に敷設し, 「落下物の落下位置が二次 元的に標定できるか」,「落下物の大きさを評価できるか」,「加速度計による測定結果との対比ではどうか」等について実験を行った。加 えて，新たに開発した移動通信網を用いたデー夕伝送システムの動作に関する実験を行った。 その結果，次の事項が明らかになった，ま たは確認された。(1)ケーブルセンサは高い精度を要求していなければ, 加速度計の代替センサとして利用できる。（2)実規模の覆道におい ても上部に鋼球を落下させた場合, 落下位置は波形の立ち上がり, 振幅, トポグラフィのいずれによっても標定できる. (3)ケーブルセン サは $6 \mathrm{~g}$ の鋼球の落下振動を検出できる. また，ケーブルセンサからの出力電圧值から落下物重量のオーダの違いを推定できる. (4)ケー ブルセンサの長さが増加すると出力の感度が落ちるが, 実験結果から仮に $100 \mathrm{~m}$ ケーブルセンサを用いても実用上十分な感度が得られる. (5)新たに開発した落石検知システムにおける携帯電話通信網による必要なデー夕量(48Kbyte)の伝送時間は現在のところ 3 分以内であり, ケーブルセンサを含めた本落石検知システムは実用に供せる可能性が高い.
\end{abstract}

Key words : ケーブルセンサ cable sensor, 落石検知 rock fall detection, 震源位置標定 source location of impact and noise，移動通信網 mobile multimedia network

\section{1.は じめに}

わが国の沿岸道路や山岳道路沿いには, 急傾斜の岩盤斜 面が多くみられ, 崩壊ないし落石の危険にさらされている 箘所屯少なくない。これらの箇所は, 通常は車両等の交通 量も少なく，また通信などの情報手段も貧弱な状況下にあ る. 最悪の場合には, 発生後数時間経過して初めてドライ バーの通報で発見されるなど問題点も多々含んでいる。 と くに今日, 情報社会や I T 革命が急速に進展するなかにあっ て, 防災上・人命尊重上の観点から見ても早急な改善策が

*1 (株)NTT ドコモ北海道取締役 NTT DoCoMo Hokkaido, Inc. (会員)

*2 (株)NTTドコモ北海道モバイルマルチメディア事業本部 NTT DoCoMo Hokkaido, Inc. (会員)

*3 北海道大学工学研究科 Graduate School of Engineering, Hokkaido University (会員)

*4 北海道大学工学研究科 Graduate School of Engineering, Hokkaido University

* 5 日立ソフトウェアェンジニアリング(株) Hitachi Software Engineering Co. Ltd.
要求されている. 一方，今日まで経験工学上，岩盤斜面に おける落石や岩盤崩落が発生する前にはしばしば破壊音や 小さい崩落音が発生する事例があり，とくに大規模な岩盤 崩落では小規模な落石が先行するなどの指摘あある ${ }^{11,2)}$. 著者らはこうした前兆的破壊現象や, 落石がトンネル巻き 出し部あるいは覆道上面に衝突するときに発生する振動を, 振動検出用ケーブルセンサで捉える取り組みを行ってき $た^{3,4)}$.

今回の研究では, 実規模覆道内にケーブルセンサを格子 状に敷設し，「落下物の落下位置が 2 次元的に標定できる か」, 「落下物の大きさを評価できるか」,「加速度計による 測定結果との対比ではごうか」等について実験を行った. 加えて, 移動通信網を用いたデータ伝送システムを新たに 開発し動作試験を行った. 本論では上記の実験結果と, 新 たに得られた知見について述べる.

\section{2. 実験箘所と実験方法}

実験には, 北海道沙流郡日高町に位置する旧国鉄富内線 の覆道を用い，覆道上部に落石に見立てた鋼球を落下させ， 


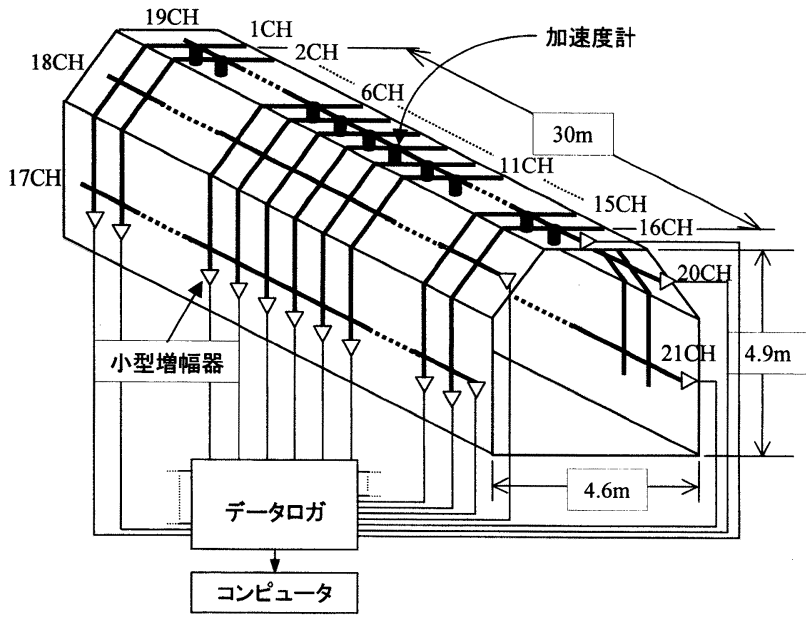

図-1＼cjkstart実験用覆道とケーブルセンサの敷設状況

ケーブルセンサの出力電圧と加速度計の測定結果を比較す る実験を行った。覆道は図-1に示すような門型の形状で, 縦および横の寸法は $4.9 \mathrm{~m} \times 4.6 \mathrm{~m}$ である。覆道の肉厚は天

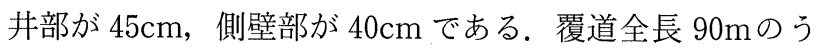
ち一端から $30 \mathrm{~m}$ 範囲をトンネルの巻きだし部に見立て た。

ケーブルセンサを覆道の周方向に 16 本 ( 2 m間隔), そ れと直交する軸方向に 5 本 ( $2 \mathrm{~m}$ 間隔)を取り付けた. ケー ブルセンサは $1 \mathrm{~m}$ おき $10 \mathrm{~cm}$ ずつ内壁へ固定した．固定 はエポキシ系接着剂で行った。縦横合計 9.1 本さなるケー ブルセンサの一端に, 小型の増幅器を取り付けケーブルセ ンサからの出力電圧を 20 倍増幅した. この小型増幅器を 通してケーブルセンサからの $21 \mathrm{CH}$ 分の波形信号はデー夕 ロガ(サンプリング速度 $100 \mathrm{kHz}$, メモリ容量 $6 \mathrm{Mbyte} / \mathrm{CH}$, $24 \mathrm{CH})$ に入力れる. データロガに蓄積されたデータをパー ソナルコンピュータに取り込み, 出力波形の表示やトポグ

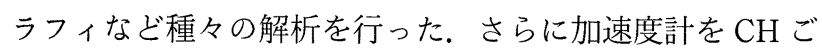
とに取り付け，ケーブルセンサとの比較計測を実施した.

以上が基本的な実験方法である。 また，本研究ではケー ブルセンサに関する計測に加えて「計測データの伝送に関 する研究」を行っており, その詳細については後述するこ ととする.

\section{3. 実験結果と考察}

\section{1 ケーブルセンサの出力電圧と加速度の関係}

$7.26 \mathrm{~kg}$ の鋼球をさまざまな高さから落下させ, 覆道に 比較的大きな衝撃を与えた，図-2〜4 は, そのときの鋼球 の落下による衝撃を, ケーブルセンサと加速度計で同時に 測定し, 両者の出力波形の最大值をプロットしたものであ る. 横軸にケーブルセンサ出力電圧, 縦軸には加速度を両 対数表示している. なお，図-5 がそのときのケーブルセ ンサと加速度計の出力波形例である. 振動の减衰時間を比 較すると, 加速度計よりあケーブルセンサの方が長く, こ

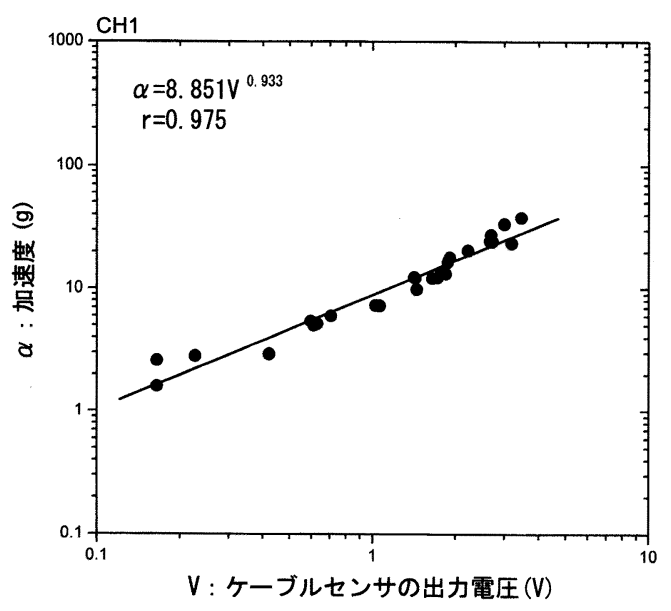

図-2 加速度とケーブルセンサ出力電圧の関係 ( $\mathrm{CH} 1$ の場合)

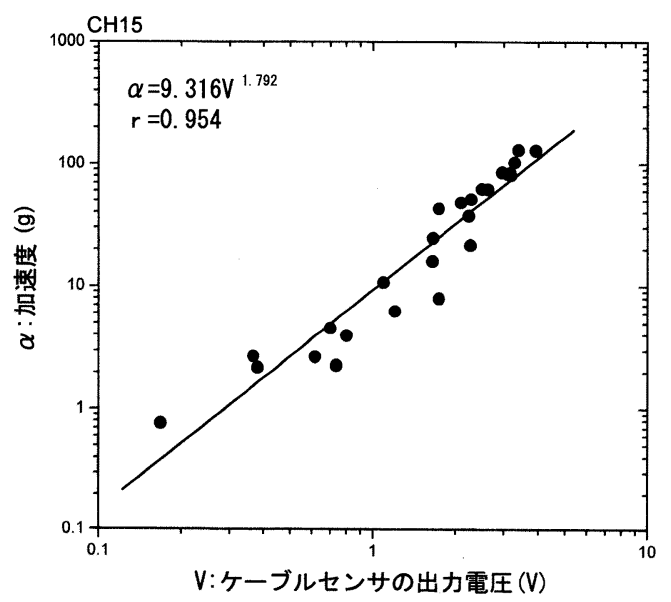

図-3＼cjkstart加速度とケーブルセンサ出力電圧の関係(CH15 の場合)

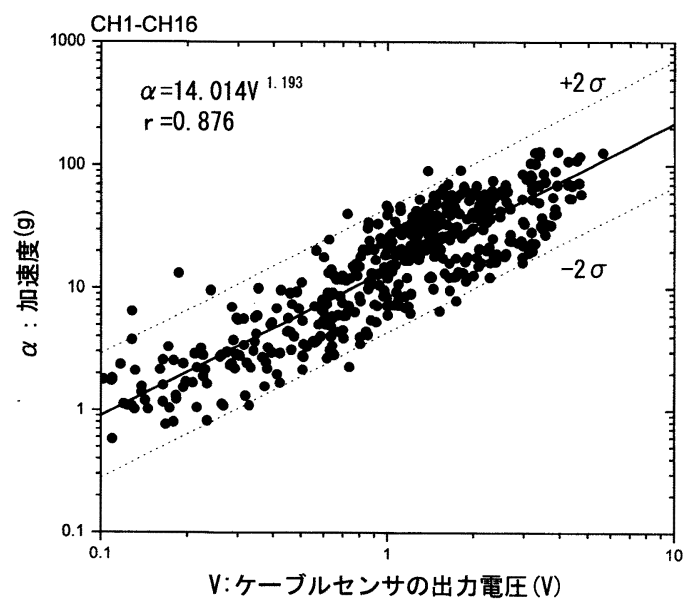

図-4 加速度とケーブルセンサ出力電圧の関係 (全 $\mathrm{CH}$ )

れまでの実験結果と同様の傾向が確認できた.

$\mathrm{CH} 1 \sim \mathrm{CH} 16$ までの周方向 $\mathrm{CH}$ のうち, 加速度計の測定 值に対するケーブルセンサの出力感度が最も大きかったも の(CH1)が図-2 であり, 一番小さかったもの (CH15)が図 -3である. CH1 から CH16 までのすべてのデー夕をプロッ トしているのが図-4である. 図-4 中に破線で示した直線 

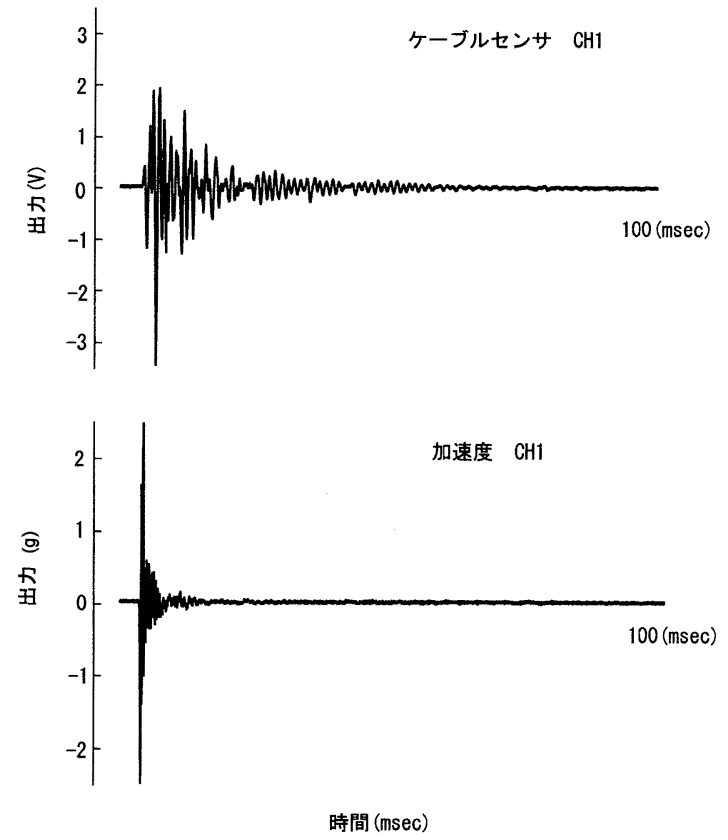

図-5ケーブルセンサと加速度計の出力波形

表-1 加速度とケーブルセンサ出力電圧に関する回帰式の係数と 相関係数

\begin{tabular}{|r|c|c|c|}
\hline $\mathrm{CH}$ & 係数 $\mathrm{A}$ & 係数 $\mathrm{B}$ & 相関係数 $\mathrm{r}$ \\
\hline 1 & 8.851 & 0.933 & 0.975 \\
2 & 17.65 & 1.15 & 0.926 \\
3 & 21.15 & 1.548 & 0.955 \\
4 & 8.17 & 0.882 & 0.866 \\
5 & 22.85 & 1.41 & 0.958 \\
6 & 20.57 & 1.174 & 0.910 \\
7 & 12.77 & 1.318 & 0.901 \\
8 & 14.53 & 1.2 & 0.961 \\
9 & 26.29 & 1.242 & 0.936 \\
10 & 13.53 & 1.415 & 0.933 \\
11 & 24.12 & 1.41 & 0.890 \\
12 & 7.221 & 1.077 & 0.962 \\
13 & 13.16 & 1.383 & 0.957 \\
14 & 10.8 & 1.465 & 0.958 \\
15 & 9.316 & 1.792 & 0.954 \\
16 & 12.25 & 1.597 & 0.954 \\
\hline $\mathrm{CH}$ & 14.01 & 1.193 & 0.876 \\
\hline
\end{tabular}

は最小 2 乗法で求めた実験式から士 $2 \sigma$ 離れた位置に引か れている. $\sigma$ はケーブルセンサの出力電圧に対する加速度 の標準偏差である。

各図中, 左上の式はとあに回帰直線のべキ関数式であり, その下の $r$ は相関係数を表している. また表-1によると， $16 \mathrm{CH}$ 中 $14 \mathrm{CH}$ 分の相関係数 $r$ は 0.9 以上の正の相関となっ ていることから, ケーブルセンサの出力電圧は加速度に変 換することが可能と言える. つまりケーブルセンサは加速 度計の代替センサとして用い得ると言える。

\section{2 ケーブルセンサのノイズレベル}

周方向ケーブルセンサ 16 本のホワイトノイズがぞの程 度のレベルであるかを調べた，実験ではポータブル発電機 から取り込んだ $100 \mathrm{~V}$ を電源に用いている。増幅倍率 20

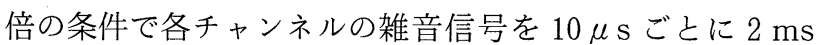

表-2 ノイズの標準偏差

\begin{tabular}{|c|c|r|r|c|}
\hline $\mathrm{CH}$ & $\begin{array}{c}\text { データ } \\
\text { 個数 }\end{array}$ & $\begin{array}{c}\text { 最大値 } \\
(\mathrm{mV})\end{array}$ & $\begin{array}{c}\text { 最小値 } \\
(\mathrm{mV})\end{array}$ & $\begin{array}{c}\text { 標準偏差 } \\
\sigma(\mathrm{mV})\end{array}$ \\
\hline 1 & 200 & 29.29 & -21.98 & 11.4 \\
2 & 200 & 29.39 & -21.88 & 11.6 \\
3 & 200 & 28.99 & -22.28 & 11.3 \\
4 & 200 & 28.69 & -22.58 & 11.8 \\
5 & 200 & 28.69 & -22.58 & 11.0 \\
6 & 200 & 29.19 & -22.08 & 10.7 \\
7 & 200 & 27.89 & -23.38 & 11.6 \\
8 & 200 & 29.29 & -21.98 & 11.5 \\
9 & 200 & 29.29 & -21.98 & 11.5 \\
10 & 200 & 28.89 & -15.05 & 11.1 \\
11 & 200 & 29.59 & -21.68 & 10.7 \\
12 & 200 & 29.09 & -14.85 & 11.0 \\
13 & 200 & 29.49 & -21.78 & 11.4 \\
14 & 200 & 29.39 & -21.88 & 11.4 \\
15 & 200 & 29.69 & -21.58 & 10.7 \\
16 & 200 & 14.00 & -7.98 & 5.6 \\
\hline
\end{tabular}

分, すなわち 200 個のデータを取り出し, バラッキが正規 分布に従うとみなして標準偏差 $\sigma$ を求めた。 その結果を表 -2 に示している。 $\sigma$ はいずれす $12 \mathrm{mV}$ 以下である。計測 信号は 500〜 $1000 \mathrm{mV}$ オーダーであり定格出力を $10 \mathrm{~V}$ と仮 定するとノイズレベルが $2 \sigma=24 \mathrm{mV}$ であれば $\mathrm{SN}$ 比は約 $52 \mathrm{~dB}$ である。この $\mathrm{SN}$ 比は市販されている低ノイズのセ ンサ類 $(60 \mathrm{~dB})$ と比較すると少し低い值であるが，実験で はポータブル発電機を用いていることああり，ノイズに対 する対策は十分とは言えない，電源の変更等を含め，ノイ ズ対策を強化することで, 改善の余地はあると考えている.

\section{3 落下位置の標定とケーブルセンサの出力波形}

実規模の覆道上に鋼球を落下させた場合においても，先 に実験室のコンクリート床を用いて行った位置標定の実験 結果 ${ }^{3)}$ およびヒューム管を用いて行った位置標定に関する 実験結果 ${ }^{4)}$ と同様, 覆道内壁に格子状にケーブルセンサを 敷設することによる落下位置の標定を試みた。

図-6〜8 は重さ $7.26 \mathrm{~kg}$ の鋼球を落下させたとき覆道の 周方向 16 本と覆道の軸方向 5 本のケーブルセンサ出力波 形を示している。図-6 は CH1 と CH19 の交点に, 図-7 は $\mathrm{CH} 7$ とH19 の交点に, 図-8 は $\mathrm{CH} 16$ と $\mathrm{CH} 19$ の交点に それぞれ鋼球を落下させたときの出力波形であり, 表示し ている横軸の時間は $100 \mathrm{~ms}$ である。いずれのグラフも落 下位置の波形振幅が最む大きく，震源から遠ざかると振幅 は小さくなっている．また振動の立ち上りを見ると落下位 置が最も早く, 震源から遠ざかると立ち上り時間が遅くなっ ている. 上記より振動波形の振幅と立ち上がり時間から鋼 球を落下させた位置を明瞭に標定することができると言え る.

次に加速時計を覆道内壁の $\mathrm{CH} 6$ 〜 $\mathrm{CH} 11$ と $\mathrm{CH} 19$ の 6 つ の交点に取り付けて, 両センサの出力を比較し, それぞれ の感度特性について調べた。覆道の CH9 と CH19 の交点 の直上に $1.04 \mathrm{~kg}$ の鋼球を $1.35 \mathrm{~m}$ の高さから落下させた場 合の実験結果例を示す。このとき加速度計は覆道内壁の 


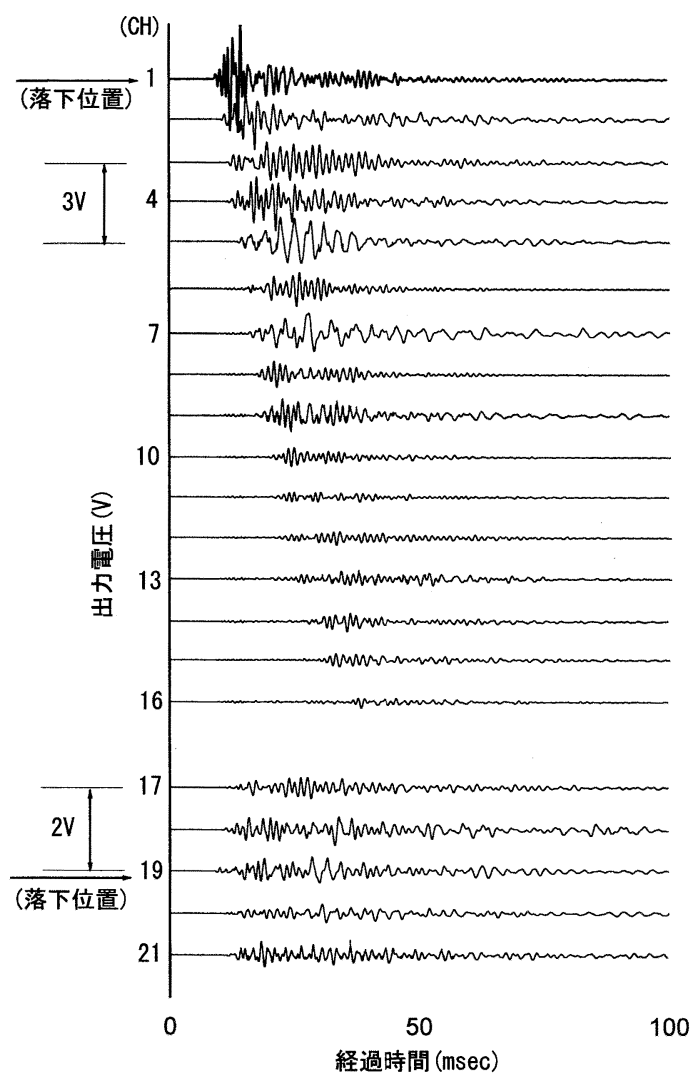

図 6 ケーブルセンサ出力波形 (CH1 と CH19 の交点に鋼球落下)

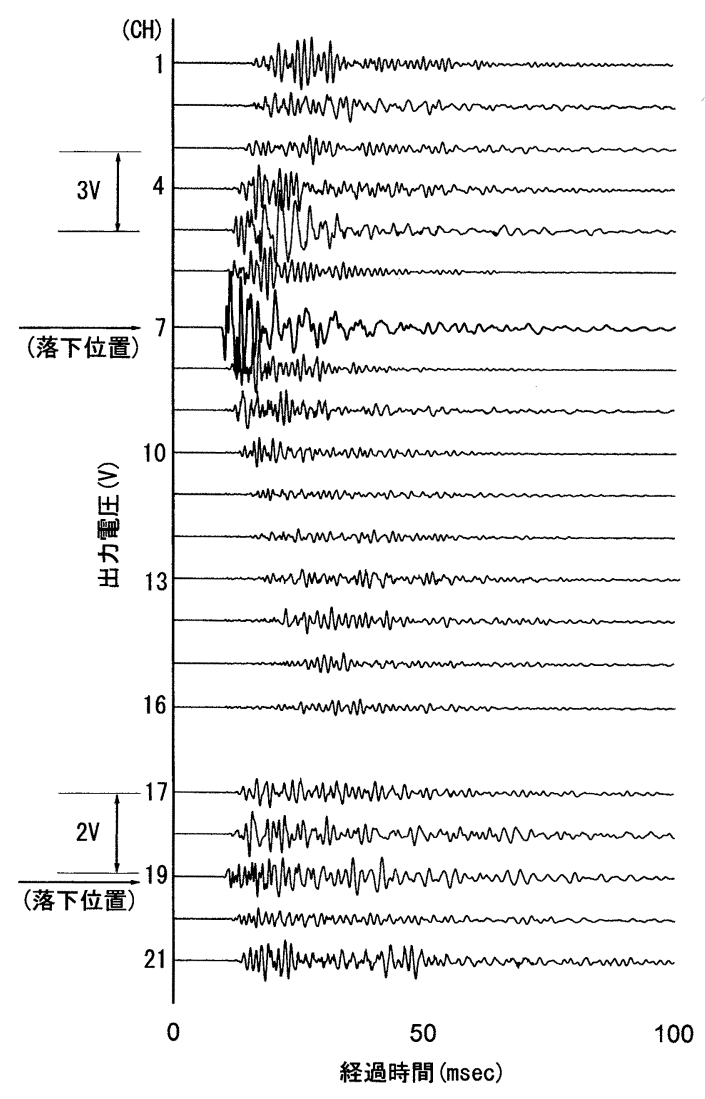

図-7ケーブルセンサ出力波形 (CH7 と CH19 の交点に鋼球落下)

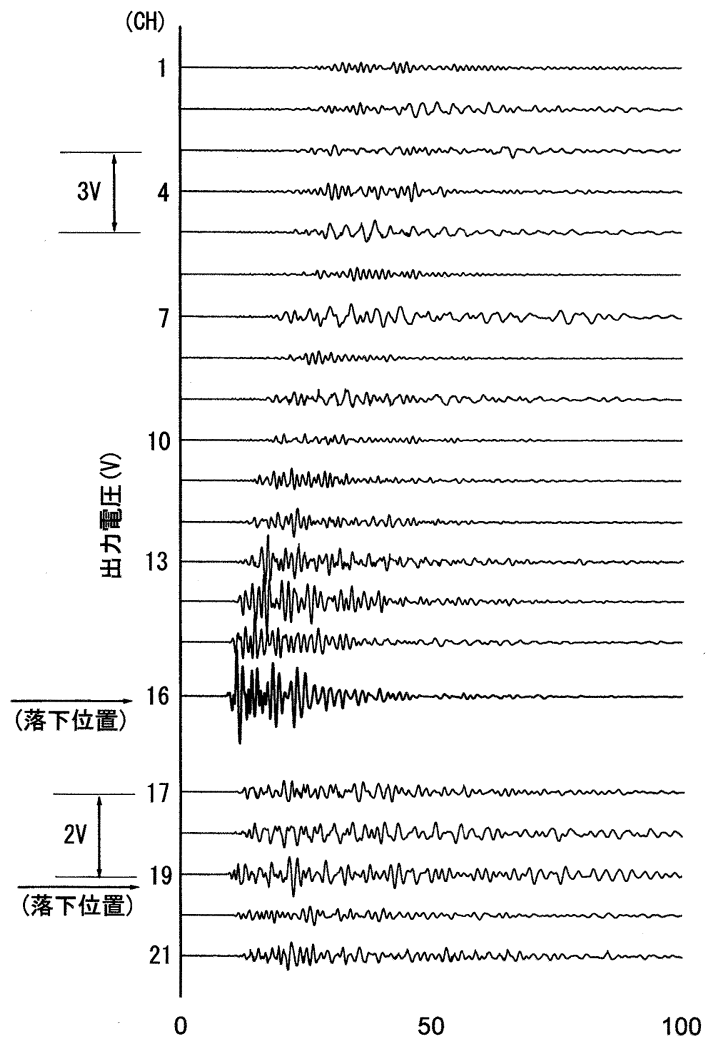

経過時間 (msec)

図-8ケーブルセンサ出力波形

(CH16 と $\mathrm{CH} 19$ の交点に鋼球落下)

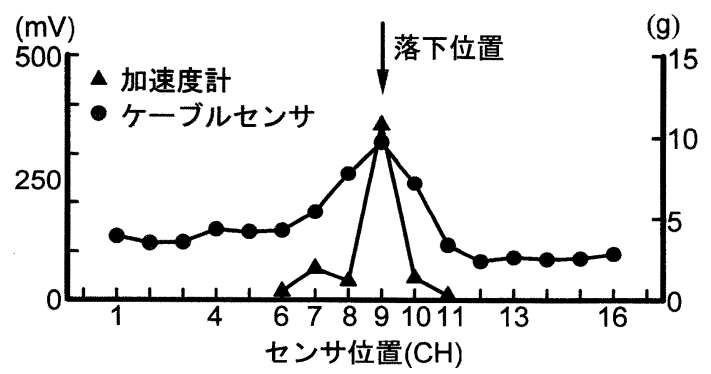

図-9 加速度およびケーブルセンサ出力電圧と震源からの距離の 関係

$\mathrm{CH}$ \% CH11 と $\mathrm{CH} 19$ の 6 つの交点に取り付けられている. 図-9 は加速度計および周方向ケーブルセンサの位置(距離) と出力の関係を一次元的に図示したあのである. 加速度曲 線は鋭角的なピークを示し震源位置の $\mathrm{CH} 9$ を明瞭に標定 できる. 一方，ケーブルセンサの出力電圧曲線は比較的な だらかなカーブになるがピーク位置は一致している。これ より, 必ずし屯精度は高くないが加速度計の代替センサと して安価で広い範囲をカバーできるケーブルセンサの利用 が落石検知上有効と考えられる.

\section{4 落下物の重量とケーブルセンサ出力電圧の関係}

覆道上に $6 \mathrm{~g}, 533 \mathrm{~g}, 1.04 \mathrm{~kg}, 2.72 \mathrm{~kg}, 4.00 \mathrm{~kg}, 5.45 \mathrm{~kg}$ の 6 種類の鋼球を $1.35 \mathrm{~m}$ の高さから落下させてケーブルセ ンサの感度試験を行った。このとき，ケーブルセンサ $\mathrm{CH} 16$ と $\mathrm{CH} 19$ の交点に加速度計も取り付け同時に加速度 


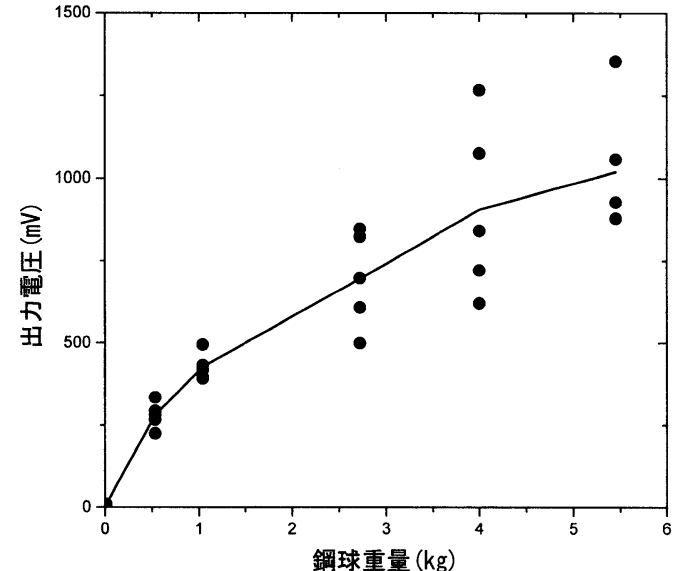

(a)ケーブルセンサ

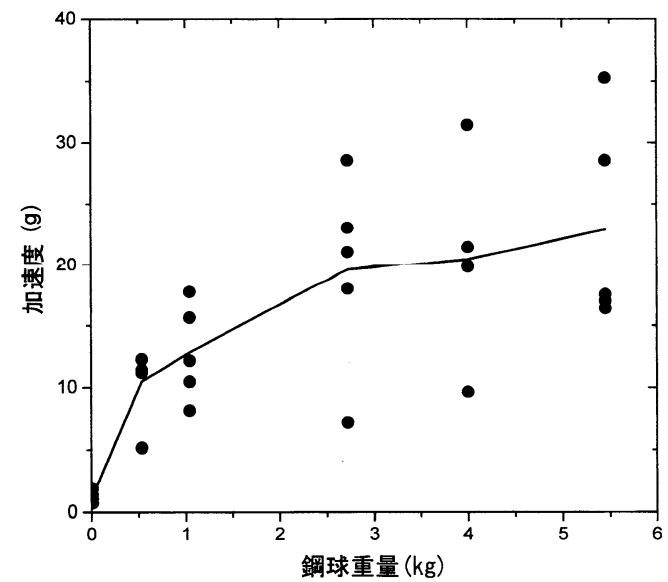

(b) 加速度計

図-10ケーブルセンサ出力電圧および加速度と落下物重力の関 係

あ測定している，落下位置は $\mathrm{CH} 16$ の直上である，実験の 結果, $6 \mathrm{~g}$ の鋼球の信号波形であ信号とノイズレベルを明 瞭に区別できることが確認された．鋼球の重量を横軸に， ケーブルセンサの出力電圧を縦軸にとり両者の関係を示し たのが図-10(a)である．図によると重量の増加に伴い出 力電圧む増加している.

このデータから落下物の重さを細かく判別することは, 出力電圧にバラッキがあるためむずかしい，ただし，同時 に測定した重量と加速度の関係を示す同図(b)を参考にす ると，バラッキの度合いはケーブルセンサ，加速度計どち らも同程度である。しかし落下物の重量の増加に伴い出力 電圧む増加する傾向を持つので, 数十, 数百または数千 $\mathrm{kg}$ といったオーダーの違いの判別は十分可能と考えられ る. 今後も実験を繰り返し, ケーブルセンサの出力電圧か ら落下物重量を判別する方法に関する研究を継続する予定 である。

\section{5 人工亀裂による微小振動と出力電圧の関係}

ケーブルセンサ利用の可能性の一つに岩盤亀裂音の検出 がある。一般に，岩盤亀裂音検出を行う場合， $\mathrm{AE}$ センサ

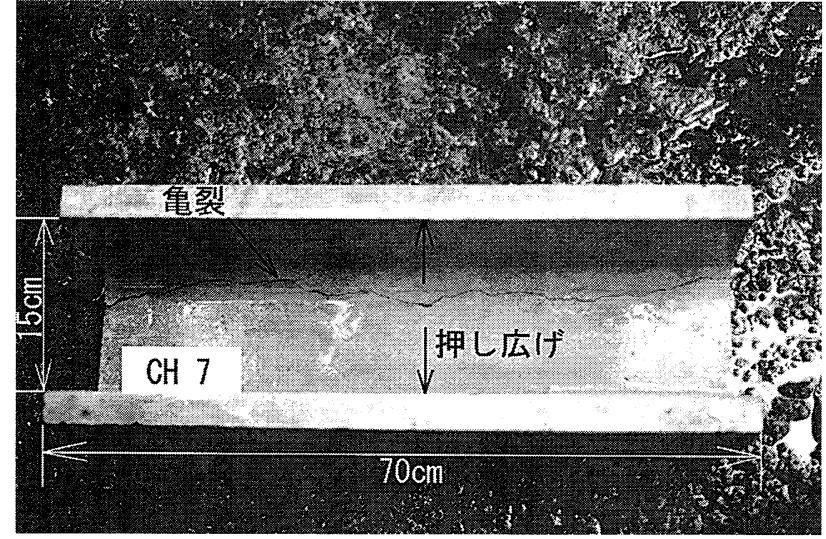

図-11Ｕ字形コンクリートへの亀裂発生状況

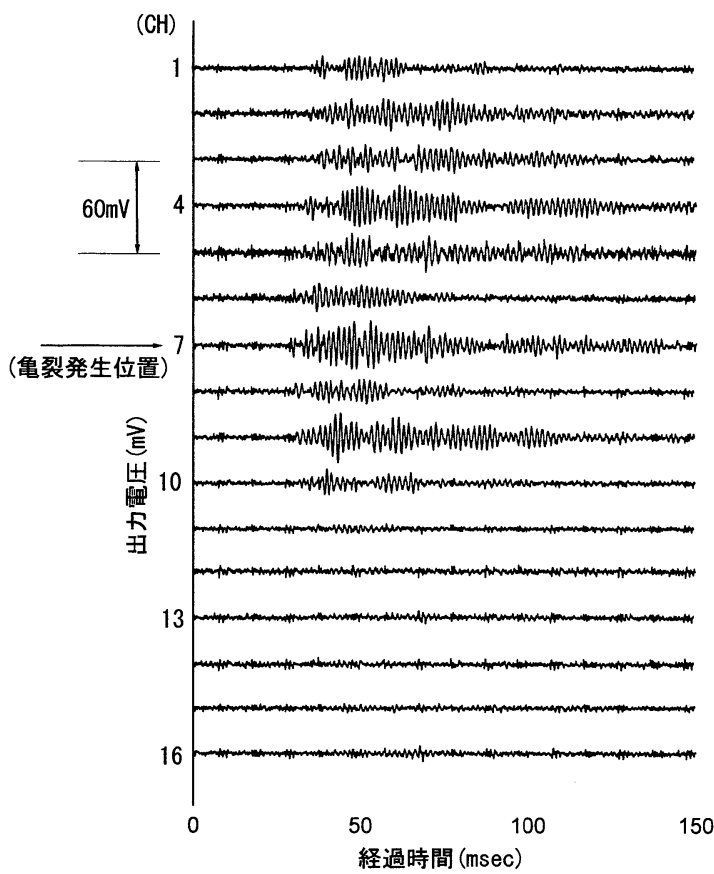

(a) 周方向全 $\mathrm{CH}$ の出力波形

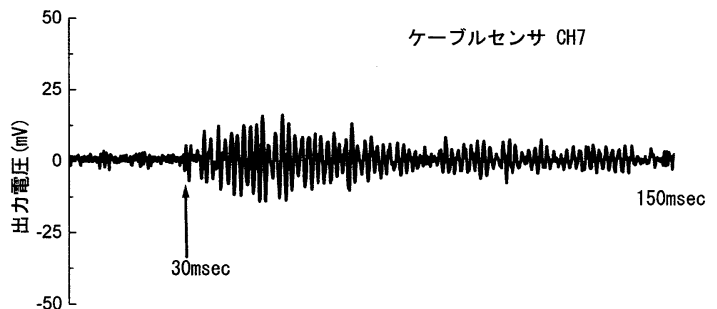

(b)CH7 のケーブルセンサの出力波形

図-12＼cjkstart亀裂発生に伴うケーブルセンサの出力波形

を用いることが多い，実際，AE センサを用いるのが最良 の方法といえるが，高感度 $\mathrm{AE}$ センサは高価でありコスト 面で優れているケーブルセンサを利用できないかと考え実 験を行った. 同じく実験は図-1の覆道で行った。ケーブ ルセンサの敷設状況はそのままとし， CH7 の上の覆道上 面にU字形コンクリートをコンクリート用接着剤で固定し, 完全に乾いた後油圧ポンプでU字部分を拡げて亀裂を発生 
させ，そのときの亀裂音をケーブルセンサで感知できるか よ゙うかを試験した。実験に用いたU字形コンクリートを図 -11に示す. 図の写真は, 油圧ポンプで亀裂を発生させた 直後の状態を示している。

U字形コンクリートに亀裂を発生させたときの，周方向 16 本のケーブルセンサの出力波形を図-12(a)に示す．亀 裂を発生させた位置は $\mathrm{CH} 7$ の直上であるが，ほかのケー ブルセンサの出力との差が小さく, 亀裂発生位置の正確な 標定は難しいがケーブルセンサで亀裂音を受感し得ること は確認された。

亀裂発生位置の $\mathrm{CH} 7$ のケーブルセンサの出力波形を拡 大して表示したものを図-12(b)に示す。亀裂音による波 形の立ち上がり時刻は同図の約 $30 \mathrm{~ms}$ の位置である。ケー ブルセンサの出力電圧は土 $20 \mathrm{mV}$ 以下である. 例えば $95 \mathrm{~g}$ の鋼球を高さ $1.35 \mathrm{~m}$ から落下させたときのケーブルセンサ の出力電圧は $100 \mathrm{mV}$ 近くあったことから, 亀裂音による ケーブルセンサの出力值は非常に小さいといえる. しかし， 0〜30ms のホワイトノイズ部分とは，明瞭に区別できる. 岩盤亀裂音検出にケーブルセンサを利用できる可能性があ るといえる。

\section{6 ケーブルセンサの長さと感度の関係}

$250 \mathrm{~m}$ のケーブルセンサを用意し，覆道の側面に設置し て, 腕の長さが $65 \mathrm{~cm}$, 重量が $7.6 \mathrm{~kg}$ のハンマーを振り子 状にして壁面に打撃を与え, そのときの出力波形を測定し た．その後ケーブルセンサを $200 \mathrm{~m}, 150 \mathrm{~m}, 100 \mathrm{~m}, 50 \mathrm{~m}$, $25 \mathrm{~m}$ と切断していき, ケーブルセンサの長さと感度の関係 を調べた。

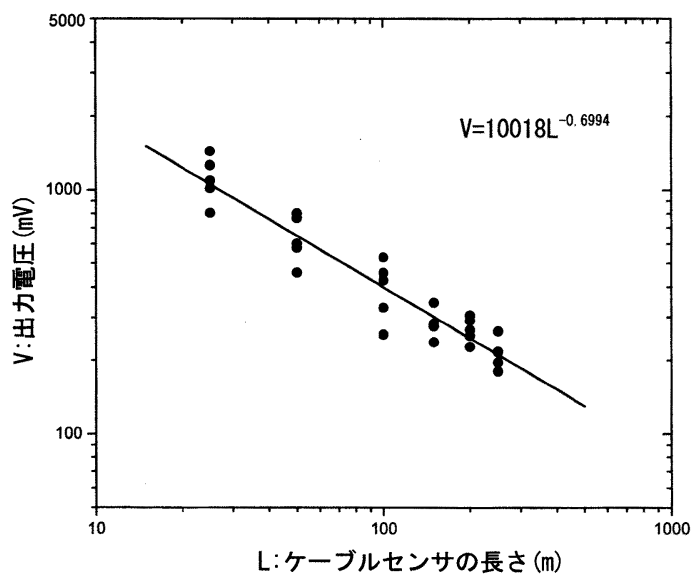

図-13ケーブルセンサの長さと感度の関係

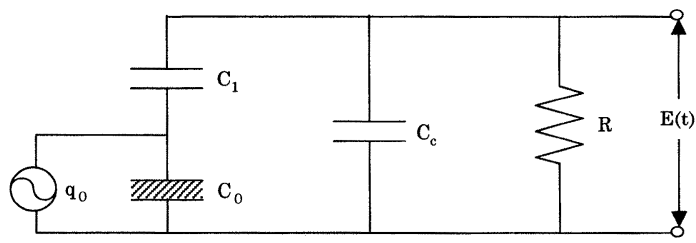

図-14ケーブルセンサを用いた測定回路
実験結果を図-13 に示す.ケーブルセンサはメーカーに より $300 \mathrm{~m}$ で使用可能とされているが，本実験により，

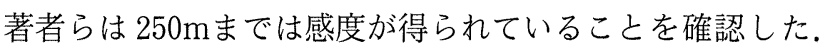
またケーブル長が短くなるほど出力電圧が上がる，つまり 感度が良くなるという傾向が得られた，これは次のように 説明することができる.

図-14 はケーブルセンサの等価回路図である，この回路 の入力と出力電圧の関係は(1)式で示される.

$$
\begin{aligned}
& \frac{d E(t)}{d t}+\frac{E(t)}{R\left(C_{c}+C_{1}\right)} \\
& =\frac{C_{1}}{C_{0}(t)\left(C_{c}+C_{1}\right)} \cdot \frac{d q_{0}(t)}{d t}
\end{aligned}
$$

$(1)$ 式の $q_{0}(t)$ は発生電荷, $E(t)$ は出力電圧, $C_{c}$ はケー ブルセンサの心線とシールド線間の全電気容量, $C_{0}$ は心 線と FEP(心線とシールド線間にある誘電材料)間の電荷 発生部に生じる局所的な電気容量, $C_{1}$ は FEP を挟んだ心 線とシールド間の局所的な電気容量, $R$ は負荷抵抗である.

ケーブル長が短くなることは $C_{c}$ が減少することを意味 する.（1)式では右辺 $q_{0}(t)$ が $\left(C_{c}+C_{1}\right)$ で除されており， $C_{c}$ が減少すれば石辺全体は增顺する。これにより左辺を解い たときの出力電圧 $E(t)$ あ増加するため, ケーブルセンサ の感度が上昇する，ただし，ケーブルセンサの長さが短か すぎると電荷を発生できる範囲が短かくなることで，（1） 式右辺の $d q_{0} / d t$ が小さくなり, 感度は逆に低下する ${ }^{3), 5)}$.

本実験結果を基に，仮に $100 \mathrm{~m}$ 四方の岩盤斜面の監視に 長さ $100 \mathrm{~m}$ のケーブルセンサを格子状に敷設した場合の感

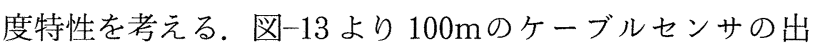
力電圧は $400 \mathrm{mV}$ と読み取れる.ノイズレベルを前述のよ うに $2 \sigma=24 \mathrm{mV}$ とすると, 電圧で約 17 倍の差を持って おり, 信号の検知は十分可能である. 先述のごとく本実験 ではハンマーの打撃による振動を入力している. 実際の落 石はこのレベルを十分超えるものと予想され, 実用上問題 はないと判断できる.

\section{4. 震源位置の図形による表示(トポグラフィ)}

震源位置や規模の大きさを判断するにあたっては，3 次 元的に図形表示したトポグラフィを用いた．表示するにあ たって，覆道やトンネルなどの曲面の場合は，それを切り 開き平面的に展開する。 つまり, 敷設されているケーブル センサのうち, 周方向を $x$ 軸 $(\mathrm{CH} 1 \sim \mathrm{CH} 16)$, 軸方向を $y$ 軸( $\mathrm{CH} 17 \sim \mathrm{CH} 21)$ とし, さらに両者の出力值(図-4 の実験 式で変換した加速度)をかけ合わせたものを格子点の值と して $z$ 軸に表示した。したがって縦軸は $\mathrm{g}^{2}$ の単位を持っ.

ここでは覆道の両端および中央部分での鋼球落下実験結 果から得られたトポグラフィを示している。図-15 は CH1 と $\mathrm{CH} 19$ の交点に, 図-16 は $\mathrm{CH} 7$ と $\mathrm{CH} 19$ の交点に, 図一 17 は $\mathrm{CH} 16$ と $\mathrm{CH} 19$ の交点にそれぞれ $7.26 \mathrm{~kg}$ の鋼球を落 
下させたときのトポグラフィである. いずれのグラフあ鋼 球の落下点とトポグラフィの頂点は一致しており, 落下位 置の標定が可能である.

なお，ケーブルセンサの出力值をそのまま用いてトポグ

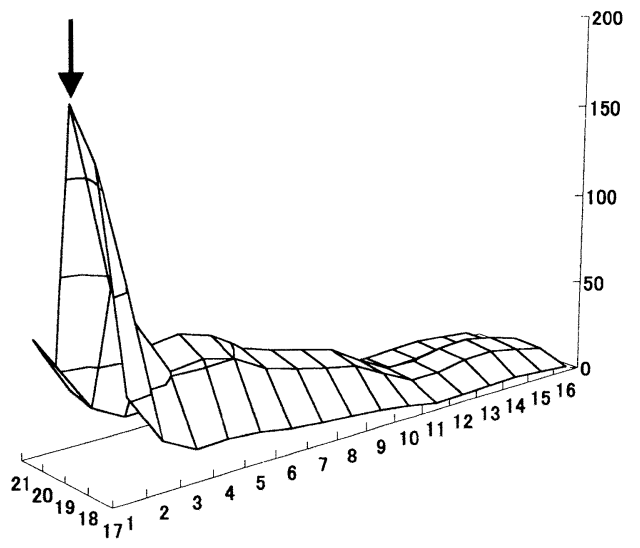

図-15＼cjkstart覆道奧部におけるトポグラフィ(CH16)

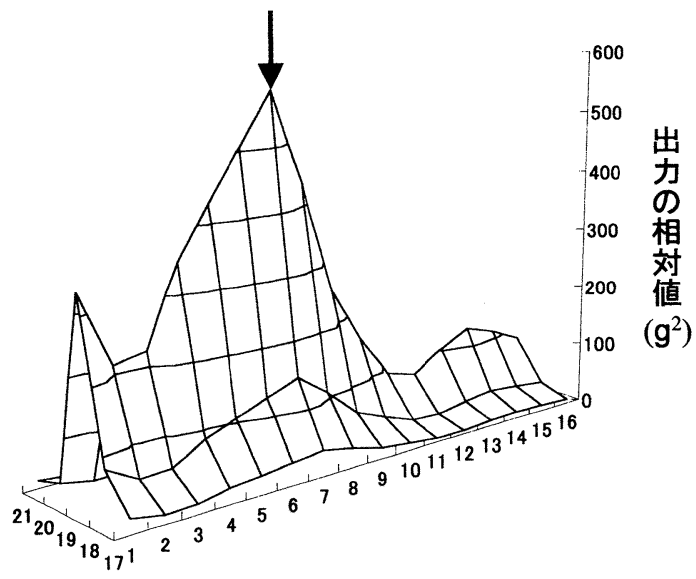

図-16＼cjkstart覆道中央部におけるトポグラフィ(CH7)
ラフィを描くと，ケーブルセンサの感度にばらつきがある

ことから，凹凸のあるトポグラフィになる，そのためここ では，隣接するケーブルセンサの出力值の移動平均をとる ことにより，滑らかで，かつ頂点を際立たせたトポグラフィ として表示している.

以上のように実規模覆道においても，落下物の震源位置 をトポグラフィで視覚的に判定し得ることが確認された.

5. 移動通信網を用いたデータ伝送システムの実験 結果

\section{1 システム構成}

実際に落石を監視しようとする際の監視室は, 覆道等の 現場から地形的にも離れた箇所, つまり既存の道路維持等 に供されている管理事務所内に設置されるのが現実的と考 えられる。フィールド実験にあたっては，「距離と時間を 克服する」という移動通信の最大の, メットを活かし，落 石現場から距離的に離れた状態でも, 計測されたデータが

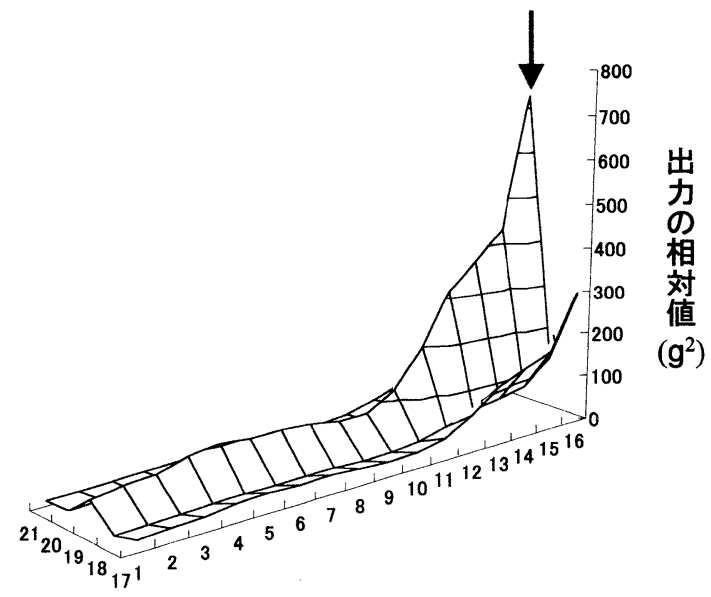

図-17＼cjkstart覆道入りロにおけるトポグラフィ(CH1)

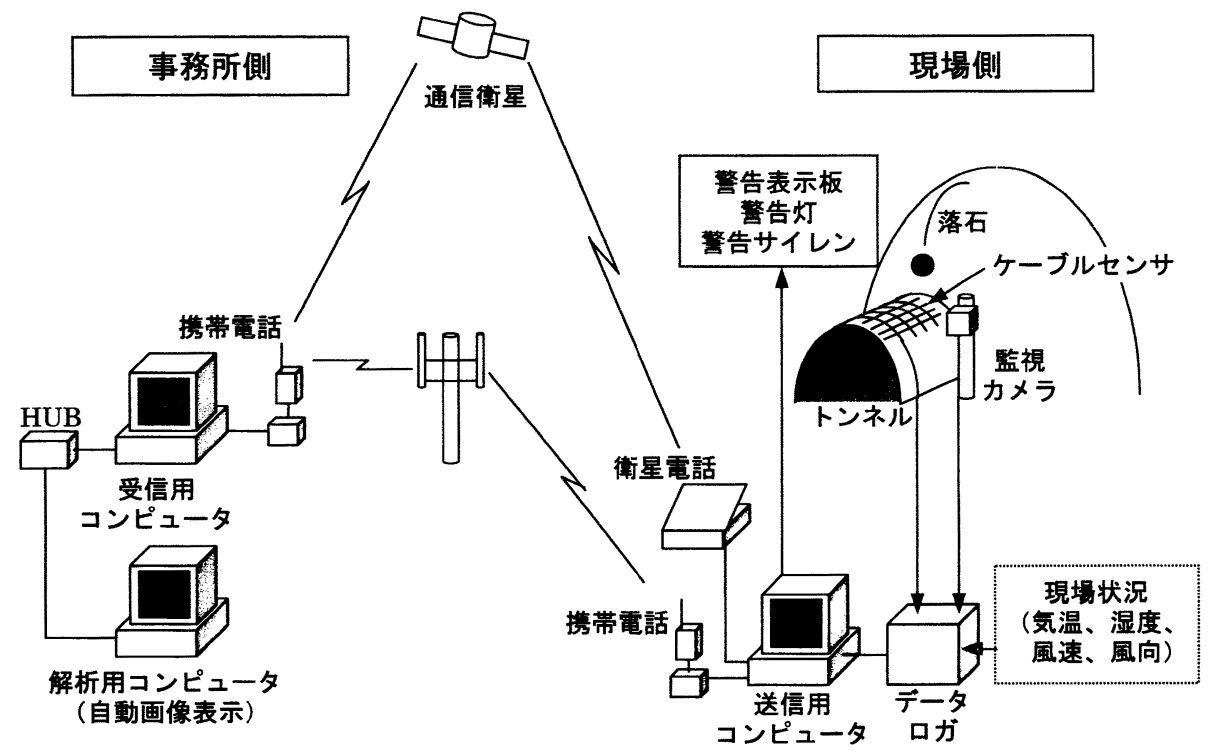

図-18＼cjkstart計測システム概念図 
監視室にスムーズに伝送されることの検証も含め実験を進 めた. 図-18は，今回行ったフィールド実験の計測システ ムの概念図を示している．計測システムは大別して現場側 (現地)と事務所側(国内であればごこでもよい)にわかれて おり，両者の間を携帯電話通信網，または衛星携帯電話通 信網で接続する構成とした。現場側は，ケーブルセンサ， データロガ, データ送信用携帯電話および現場側コンピュー 夕で構成され，また，事務所側は受信用携帯電話，受信お よびデー夕解析用コンピュータで構成されている.

\section{2 システムの動作概要}

覆道上に鋼球を落下させるとケーブルセンサからの信号 によりデータロガのトリガがかかり，信号の取り込みが始 まる。また同時に警告用電光表示盤へ「異常の発生」とい う表示を行う。次にデータロガへのデータ取り込み後, 現 場側コンピュータ内に現象開始から $100 \mathrm{~ms}$ ，および $200 \mathrm{~ms}$ 問の波形表示用データファイルを作成する。さら に $200 \mathrm{~ms}$ データファイルを用い FFT(高速フーリエ变換) 処理を行い FFT データファイルを作成する。このうち各 $\mathrm{CH}$ の波形の最大值 (十側), 最小值 (一側)を読みとったも のと，むとの $100 \mathrm{~ms}$ データファイルの 2 つを伝送試験用 データファイルとした.

ファイル作成後, 現場側隽帯電話または衛星携帯電話か ら事務所側携帯電話を呼び出し, 伝送試験用データファイ ルを伝送した。 その際のデー夕容量は $48 \mathrm{Kbyte}$ であった。 通信終了後落下位置と相対的な振動の強さを示す図形であ るトポグラフィを事務所側コンピュータのディスプレイ上 に自動表示させた。同時にあう一台のディスプレイ上に各 $\mathrm{CH}$ の振動波形と最大・最小值を自動表示させた.

以上がシステム動作の流れであり処理の過程を図-19に 示した。

実際に北海道内の山間部で行った現地テストでは，実験 現場から数 $\mathrm{km}$ 離れた事務所において鋼球落下による卜 ポグラフィを図-20のように表示することができた。現象 発生からデー夕伝送, 図形表示までに約 3 分を要した。し かし，実験の度に時間のバラッキが認められた。このバラ ツキがどの程度であるかをみるために次の伝送時間に関す るテストを行った.

\section{3 データ伝送時間}

図-21 はデー夕伝送時に, コンピュータに行わせる時系 列的な処理の内容之現象発生からの時刻を示している。図 の中で，幅のある矢印で示した箇所，すなわち，携帯電話 の接続時間, デー夕伝送時間，図形表示時間にばらつきが 認められた。接続時間は送信側コンピュータが接続開始の メッセージをディスプレイ上に表示してから接続終了のメッ セージを表示するまでの時間である.

現場試験では通信時間に関する十分な試験を繰り返して いなかったため, 改めて札幌市内のビル内部で 56 回のテ

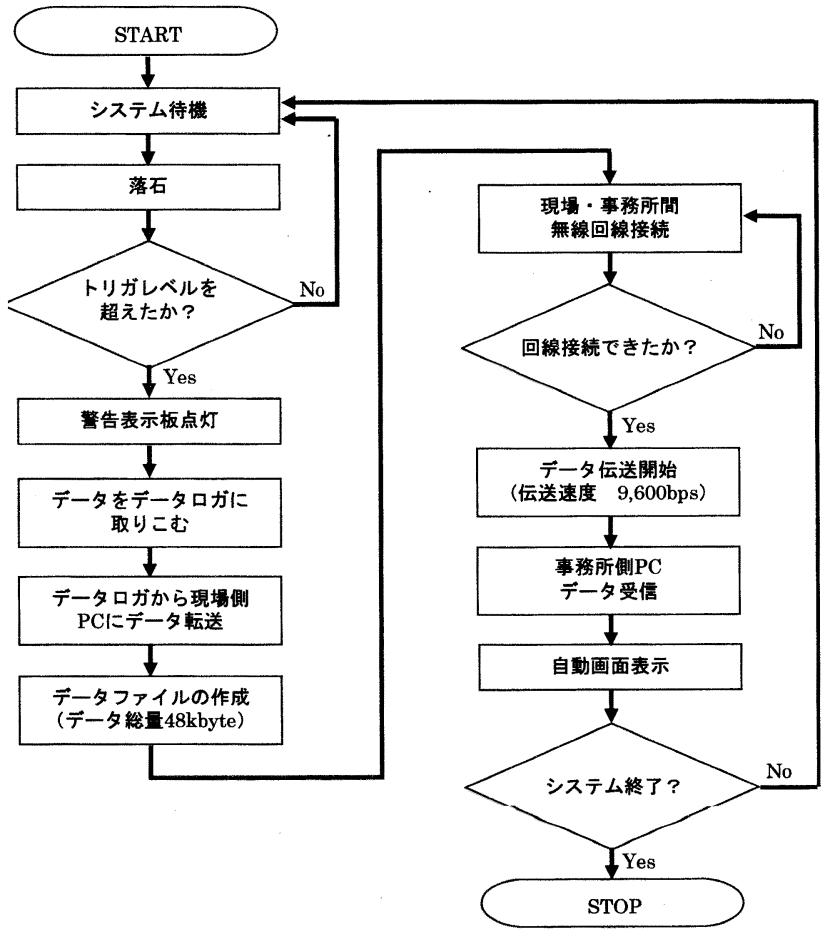

図-19 信号処理の流れ

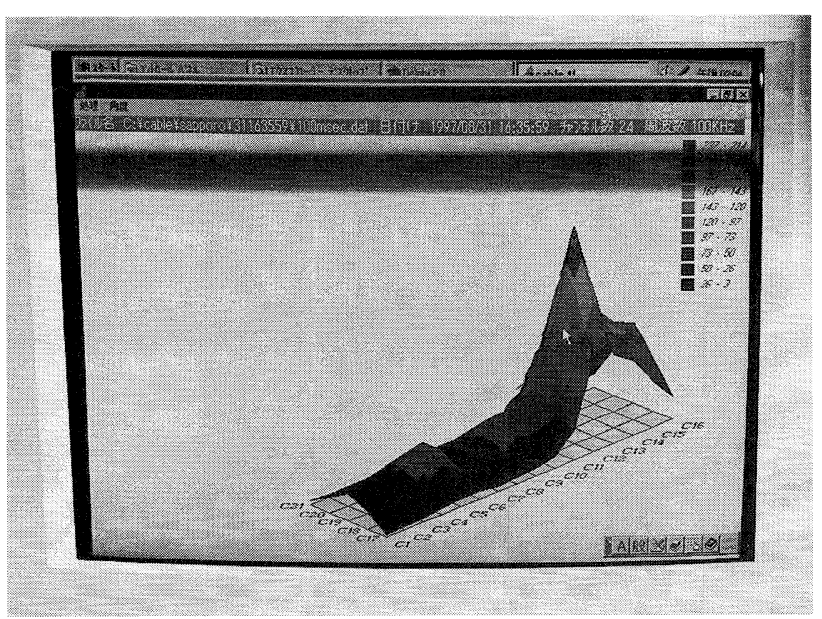

図-20 受信側コンピュータ上におけるトポグラフィの表示例

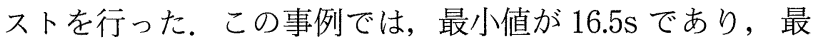
大值は $22.0 \mathrm{~s}$ であった。最小值が理論的最小值に近いと仮 定し, 測定データから最小值を引いた差のヒストグラムを 示しているのが図-22(a)である。図の分布にはWeibull 分布 ${ }^{6}$ をあてはめることとした。 この場合，例えば，接続 できる確率が 99\%である時間は図に示した実験式から $21.2 \mathrm{~s}$ 亡算定できる. 同様の処理をデー夕伝送時間につい て行ったのが図-22(b)であり，デー夕伝送が終了できる 確率が 99\%である時間は同じく図中の実験式から 94.1s で あると算定できる、これより現象発生から図形表示までに 要する時間は $171.1 \mathrm{~s}$ と推定され, 3 分以内で確実に終了 することが確認された。

移動通信網の伝送速度は $9.6 \mathrm{Kbps}$ であるが，今後 


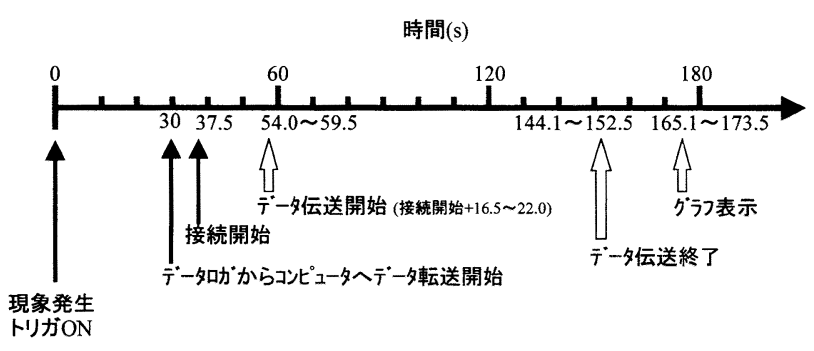

図-21 データ伝送における処理の流れ

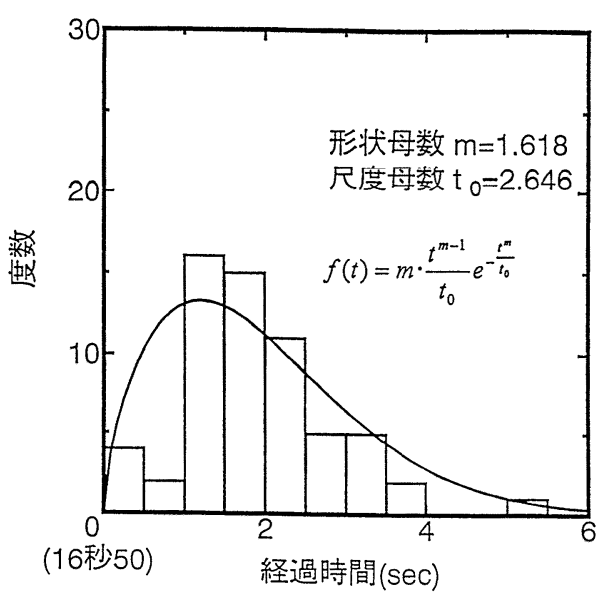

(a) 接続時間の確率密度

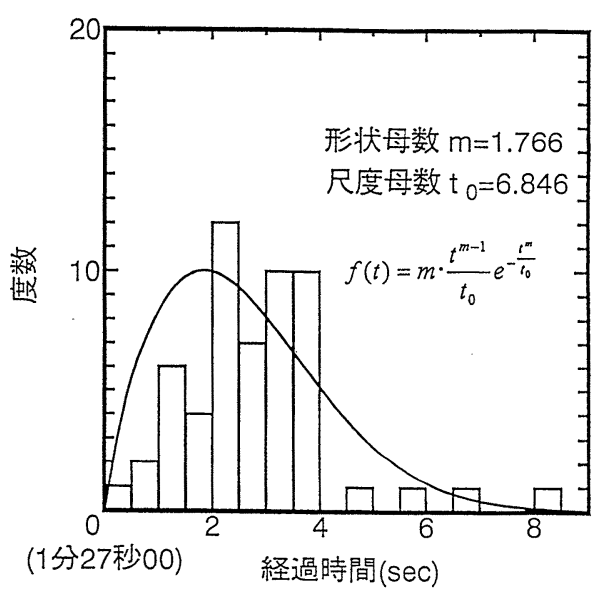

（b）デー夕伝送時間の確率密度

図-22 携帯電話接続時間とデータ伝送時間のバラッキ

2Mbps まで高速化される計画がある。またコンピュータ の処理速度む高速化しており, 現時点では 3 分を要してい るものの，近い将来この半分近くまで短縮できるあのと期 待できる.

\section{6. ま と め}

以上，本論ではケーブルセンサと移動通信網を用いた落 石検知システムの構成と実規模の覆道を用いて行った落下 物震源位置の検知之規模の推定実験の結果およびデー夕伝 送試験の結果を述べた。

実際の覆道やトンネル巻き出し部ではほとんどの場合敷
砂，EPSなどの緩衝材が敷設されている。これらが介在 する条件下でのケーブルセンサの応答についても実験を重 衫る必要がある。また, 落石防護用ネットや斜面の岩盤に 直接設置することや，屋外となるための冬期のメンテナン ス, 冬期の通信システムの保証等についても検討しなけれ ばならない。

以上のような研究課題が残されているが，本研究で得ら れた知見および確認された事項をまとめると次のようであ る.

1)ケーブルセンサは高い精度を要求しなければ, 加速度 計の代替センサとして利用できる。

2 ) 実規模の覆道においても上部に鋼球を落下させた場合, 落下位置は波形の立ち上がり, 振幅, トポグラフィのい ずれによっても標定できる.

3) ケーブルセンサは $6 \mathrm{~g}$ の鋼球の落下振動を検出できた. また, ケーブルセンサ出力電圧値から落下物重量のオー ダーの違いを推定できる.

4 ) ケーブルセンサの長さが増加すると出力の感度は落ち るが, 害験結果から仮に 100mのケーブルセンサを用い ても実用上十分な感度が得られることを確認した。

5 ) 新たに開発した落石検知システムに招ける移動通信網 による必要なデー夕量(48Kbyte)の伝送時間は現在のと ころ 3 分以内であり，ケーブルセンサを含めた本落石検 知システムは実用に供せる可能性が高い.

謝辞 本研究の現場実験は, 日本鉄道建設公団北海道支社, 苫小牧市日榮工業(株), 日高町, 北海道営林局日高営林署, 北海道開発局室蘭開発建設部各位のご理解を得て行うこと ができた。記して厚く感謝の意を表する.

\section{引用 文 献}

1) 平野昌繁・諏訪浩・藤田崇・奥西一夫・石井孝行 (1990)：1989 年越前海岸落石災害における岩盤崩壊過程の考察, 京都大学 防災研究所年報, No.33, B-1, pp.219-236.

2）佐藤博文・三上芳正・野地正保・木村彰宏 (1998)：AE 直接法 による落石岩盤崩落の監視, 北海道応用地学合同研究会論文 集 No.9, pp.113-118.

3）小川健太・氏平增之・鈴木新吾・細谷昭悟 - 石井文明(1998): 振動検出用ケーブルセンサの出力特性と応用に関する研究, 応用地質, Vol.39, No.4, pp.380-390.

4）氏平増之・鈴木新吾・細谷昭悟・佐伯浩・川北稔(1998)：ケー ブルセンサによる模擬トンネルへの落下物衝突位置の標定に 関する研究, 応用地質, Vol.39, No.5, pp.423-432.

5）中井健司・佐藤昌志・今野慎也・ 氏平増之(1999)：連続衝撃 測定センサを用いた落石感知に関する基礎試験, 土木学会北 海道支部論文報告集 No.55(A), pp.62-67.

6) 塩見弘 (1975)：信頼性工学入門, 丸善書店, pp.50-56. ( 2000 年 3 月 27 日受付, 2000 年 5 月 17 日受理) 
Jour. Japan Soc. Eng. Geol., Vol.41, No.4, pp.200-209, 2000

\title{
Field Study on the Rock Fall Detection System Using Cable Sensor and Mobile Multimedia Network for a Rock Shed of Practical Scale
}

\author{
Masaaki KOMAZAKI, Kazuo HIRAMA, Fumito ITO, Masuyuki UJIHIRA, Shingo \\ SUZUKI, Youhei KAWAMURA and Kiyoshi HIGUCHI
}

\begin{abstract}
Cable sensor is considered to have a distinctive characteristic to be able to extend a monitoring area for rock failure or rock fall detection. In this study, it was studies if the impact point of fallen rock to rock shed could be evaluated two dimensionally and if the weight of a fallen rock could be evaluated from the measured signals, and characteristics of wave forms of cable sensor was analyzed comparatively with those of accelerometer. Where, cable sensors of 21 strings were stretched in grid pattern of the internal surface of a rock shed of practical scale. Moreover, functiuns of newly developed signal transmission system using mobile multimedia network was examined. From these field studies, following points have been made clear:

1) Cable sensor can be used insted of accelermeter for rock failure and rock fall detection when high accuracy in not required. 2)Impact point caused by a weight dropping can be evaluated from rise time of wave forms, from amplitudes of wave forms and also from topography drawn using peak values of wave forms. 3) Order of the weight can be estimated from the amplitude of wave forms. 4) Sensitivity decreases when the length of a cable sensor becomes longer than several meter. But it was confirmed that enough sensitivity could be obtained when the length was longer than 100m. 5)It can be said that signal transmission system using mobile multimedia network can be used practically, because data transmission time from the impact initiation to the final displays of transmitted wave forms and topography on a remote computer is within only three minutes.
\end{abstract}

Key words : cable sensor, rock fall detection, source location of impact and noise, mobile multimedia network 